\title{
Importance of zooplankton patches in foraging ecology of the planktivorous reef fish Chromis chrysurus (Pomacentridae) at Kuchinoerabu Island, Japan
}

\author{
Mikio Noda', Keiichiro Kawabata ${ }^{2}$, Kenji Gushima ${ }^{1}$, Shunpei Kakuda $^{1}$ \\ ${ }^{1}$ Hiroshima University, Faculty of Applied Biological Science, Laboratory of Fisheries Biology, Higashihiroshima-shi, \\ Hiroshima 724, Japan \\ ${ }^{2}$ Eisai Corporation Limited, Koishikawa 4-6-10, Bunkyo-ku, Tokyo 112-88, Japan
}

\begin{abstract}
Short-term dynamics of prey-sized zooplankton and predation responses of the adult pomacentrid fish Chromis chrysurus were examined at Kuchinoerabu Island, near Yaku Island, Japan, from June 1986 to August 1987. Adult C. chrysurus fed primarily on larger planktonic copepods (ranging from 0.8 to $5.5 \mathrm{~mm}$ body length) that originated offshore, despite the dominance of smaller ones $(<0.8 \mathrm{~mm})$ in the water column. Siphonophores, appendicularians and chaetognaths were also utilized. Low overall densities $\left(<50 \mathrm{~m}^{-3}\right)$ of such zooplankton prey were common in the water column, whereas high densities (more than $500 \mathrm{~m}^{-3}$ ) occurred rarely. Dense aggregations of prey (3144 to $6475 \mathrm{~m}^{-3}$ ), including numerous large pelagic zooplankters, were recorded on 2 occasions. Differences in prey density were not detected among sampling times, nor among tide range classes. Pump-assisted plankton sampling from 07:00 to 19:00 h was conducted on 3 occasions of spring tides; however, prey densities remained extremely low $\left(0\right.$ to $\left.25 \mathrm{~m}^{-3}\right)$ during almost all of the diurnal active period of the fish. A high proportion of fishes (31 to $59 \%$ ) sampled each month, regardless of season, had empty stomachs. On the other hand, composition analysis of satiated stomachs showed that adult $C$. chrysurus utilize high density zooplankton patches when available. No diel or tidal periodicity in feeding pattern was detected, either in feeding rates or in stomach fullness, although significant differences were detected both among feeding rates and among sets of stomach fullness of specimens sampled together. Hence, adult $C$. chrysurus feed intermittently on available prey, according to fluctuations in prey density, and are probably subject to extreme food deprivation. Zooplankton patches are therefore an indispensable food resource at Kuchinoerabu Island. The possibility is discussed that adult $C$. chrysurus may take positive action in foraging behavior, in order to efficiently utilize zooplankton patches.
\end{abstract}

\section{INTRODUCTION}

Numerous studies have contrasted the feeding of reef fishes feeding on zooplankters with that of reef fishes feeding on benthic invertebrates, principally in relation to food resource availability. Such contrasts are based primarily on the recognition that zooplankton would generally be an instantaneously renewable and abundant resource by comparison with benthic invertebrates (Fishelson et al. 1974, Fishelson 1977. Brock et al. 1979, Ralston 1981, Hartney 1989, etc.). However, this is applicable only when planktivorous reef fishes occupy a suitable habitat, with a plentiful zooplankton resource. In fact, recent studies have suggested that planktivorous reef fishes are limited by food availability. Differences between different localities in relative abundance of planktivorous reef fishes are probably associated with differences in zooplankton abundance (Hobson \& Chess 1978, Gladfelter et al. 1980. Williams \& Hatcher 1983, Hamner et al. 1988, Hobson \& Chess 1988). In recent studies, the supply of zooplankton differed greatly at different reefs, sites, or locations examined (de Boer 1978, Hobson \& Chess 1978, Bray 1981, Williams et al. 1988). In addition, food abundance may affect distribution patterns (Bray 1981), growth (Thresher 1983, Jones 1986, Forrester 
1990) and reproductive activities (Thresher 1983) of planktivorous reef fishes. Thus, food availability, as well as recruitment, appears to play an important role in determining population size of planktivorous reef fishes (Forrester 1990).

Several workers have clarified behavioral aspects of foraging ecology in planktivorous reef fishes, including diel change in foraging behavior (Fricke 1970), relationships between foraging behavior and environmental factors such as water current and light intensity (Stevenson 1972), effect of social groups on prey-size intake (Coates 1980), and influence of water currents and prey densities on daily foraging movements (Bray 1981). Bray et al. (1981, 1986) showed, furthermore, that the behavioral adaptation of daily foraging movements may be related to enhanced nutrient input. Reese (1978) discussed the use of space by planktivorous reef fishes in terms of effective food capture, focusing attention on the fact that unlike benthic organisms, planktonic food is patchily distributed throughout the 3-dimensional water column.

Several studies on reproductive behavior have also paid attention to the effects of food distribution on mating systems and life-history strategies of planktivorous reef fishes, as well as to the interactions between individual males and females (Fricke 1980, Hourigan 1989, Fitch \& Shapiro 1990, Schultz \& Warner 1991).

Although the studies described above showed the importance of the food resource or dealt with subjects closely related to food availability, they emphasized only the distribution of food or the relationship of zooplankton abundance to the distribution pattern of planktivorous reef fishes, rather than the dynamics of the food resource itself.

Noda et al. (1990) demonstrated that zooplankton, in particular pelagic copepods, tended to fluctuate greatly in abundance and composition within a short term, on the basis of daily net sampling on $50 \mathrm{~m}$ fixed lines, and thus can be characterized as a rapidly changeable and dynamic resource. Moreover, the recognition of such changeability of a zooplankton resource allowed Noda et al. to clarify the role of adaption in the foraging behavior of an omnivorous pomacentrid fish feeding principally on zooplankton. However, they did not establish a temporal pattern of short-term fluctuations in the availability of the zooplankton resource, or deal with reef fishes specializing in zooplankton feeding.

In this paper, we consider in detail the characteristics and composition of zooplankton in the water column, in relation to short-term fluctuations in density. Subsequently, we describe responses of the planktivorous pomacentrid fish Chromis chrysurus to such fluctuations in the zooplankton resource. Finally, on the basis of these results, we discuss exploitation of the food resource by these planktivorous reef fishes.

\section{METHODS}

Study site. All field work was conducted in Nishiura and Honmura Bays, Kuchinoerabu Island $\left(30^{\circ} 28^{\prime} \mathrm{N}\right.$, $\left.130^{\circ} 12^{\prime} \mathrm{E}\right), 12 \mathrm{~km}$ northwest of Yaku Island, Japan (Fig. 1). Kuchinoerabu Island is strongly influenced by the Kuroshio current, resulting in Honmura Bay having an average surface temperature of approximately $24{ }^{\circ} \mathrm{C}$ (ranging from $30^{\circ} \mathrm{C}$ maximum in summer to $19^{\circ} \mathrm{C}$ minimum in winter). Nishiura Bay appears to have a similar surface temperature range. Superimposed on the Kuroshio current, is a NW-SE current which reverses direction depending on the state of the tide, in the vicinity of Kuchinoerabu Island. Similarly, in the inshore area (Fig. 1) of the Nishiura Bay study site, a NNE current tends to occur during the flood tide and a SW current during the ebb tide. These currents carry zooplankton past the island, providing a potential source of food for the resident population of reef fishes. The Nishiura Bay study site is, on the whole, a gradually sloping reef. The inshore area, with a

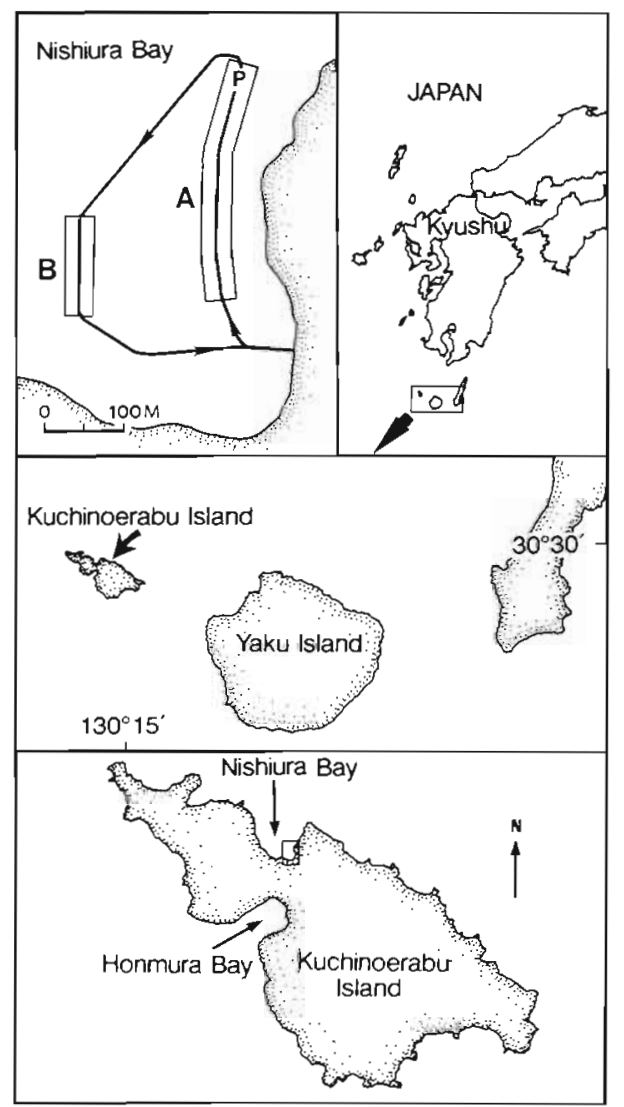

Fig. 1 Location of Kuchinoerabu Island and details of the snorkeling course and sampling pump position for plankton (P) at Nishiura Bay study site. The course was subdivided into inshore $(A)$ and offshore $(B)$ on the basis of water depth and likelihood of exchange of fish aggregation members from each locality 
channel 4 to $6 \mathrm{~m}$ deep, ranges from 2 to $8 \mathrm{~m}$ in depth, and slopes gently to an offshore area 10 to $15 \mathrm{~m}$ deep, fronting an open sandy bottom.

Specimen collection and stomach content analysis. All adult Chromis chrysurus were collected from a snorkeling course (see Fig. 1) in the Nishiura Bay study site and its vicinities, and on the northwest side of Honmura Bay, by spear gun or monofilament net, between 06:00 and 18:00 h. Immediately after collection, specimens were preserved in $10 \%$ buffered formalin, with the abdomens deeply incised. A total of 132 specimens were used for stomach content analysis. Total length and wet body weight of each specimen were measured in the laboratory. The stomachs were removed and the contents weighed in a wet condition. For all specimens, gravimetric fullness of the stomach was calculated as (SW/BW - GW) $\times 1000$, where SW, BW and GW are the weights of the stomach contents, the intact fish and the gonad, respectively. Further, in regard to the effect of breeding activities on the feeding of adults, their sexes were determined and gonad somatic indices calculated as $(\mathrm{GW} / \mathrm{BW}) \times 100$.

The stomach contents of 92 individuals were examined under a binocular microscope, sorted, and identified to class or order. Copepods were further subdivided to genus. Each food item was placed on a glass slide fitted with a rectangular metal frame about $1 \mathrm{~mm}$ in thickness, and the volume obtained by measuring the area covered by each item when level with the top of the frame. The length of intact food items was measured to the nearest $0.1 \mathrm{~mm}$. For several prey organisms, the length, width and height of each were measured, the resulting volume being taken as representative of the organism. A centrifuge tube was also used for estimating volume of many food items. The relative importance of each food item was expressed as follows: (1) percentage frequency of occurrence, (2) numerical percentage of each food item of the total number of all food items, and (3) volumetric percentage of each food item of the total volume of all food items

During fish sampling, it was important for specimens to reflect normal conditions, rather than sample bias. For this reason, fish collecting was restricted to between 2 and 6 individuals at a time and conducted on several days in each month from June to October 1986 , with the exception of one day (23 October) when daily periodicity in stomach fullness was examined. At that time a total of 27 individuals were collected from the offshore area of the Nishiura Bay study site 106:30 to 07:00 h, 7 ind.; $09: 30$ to $10: 00 \mathrm{~h}, 6$ ind,; $11: 30$ to $12: 00 \mathrm{~h}$, 5 ind.; $14: 30$ to $15: 00 \mathrm{~h}, 7$ ind.; $17: 30$ to $18: 00 \mathrm{~h}, 2$ ind.). Detailed collection data for 132 specimens used for stomach content analysis are as follows: June, 25 ind. (total of 8 collecting days) in Nishiura Bay and 4 ind.
(1 collecting day) in Honmura Bay; July, 13 ind. ( 3 d) in Nishiura Bay; August, 23 ind. (6 d) in Nishiura Bay and 9 ind. ( 3 d) in Honmura Bay; September, 2 ind. (1 d) in Nishiura Bay and 11 ind. (3 d) in Honmura Bay; October, 32 ind. ( 3 d) in Nishiura Bay and 13 ind. (3 d) in Honmura Bay.

Tests of stomach fullness between the Nishiura and Honmura Bay study site specimens collected in August and October showed no significant differences (2sample $t$-tests; August: $t=0.020, \mathrm{df}=30, \mathrm{p} \gg 0.8$; October: $t=1.116, \mathrm{df}=43, \mathrm{p}>0.2$; data log transformed). All specimens from the 2 study sites were, therefore, pooled for stomach content analysis.

Feeding behavior and plankton sampling. We observed aggregations of adult Chromis chrysurus and sampled plankton, while snorkeling a fixed course about $1 \mathrm{~km}$ long (Fig. 1) between 23 September and 21 October 1986 at the Nishiura Bay study site. The course was determined so as to include locations where we were likely to find aggregations of adult C. chrysurus. Each survey took about $2 \mathrm{~h}$ to complete Two surveys were conducted per day, in accordance with the following schedule: Day $1,06: 00$ to $08: 00 \mathrm{~h}$ and 12:00 to $14: 00 \mathrm{~h}$; Day 2, 08:00 to $10: 00 \mathrm{~h}$ and 14:00 to $16: 00 \mathrm{~h}$; Day 3, 10:00 to $12: 00 \mathrm{~h}$ and $16: 00$ to $18: 00 \mathrm{~h}$. This 3 rotating schedule was repeated 6 times, resulting in 36 surveys. For each encounter with adult C. chrysurus, the observer recorded time and location, number of individuals, type of feeding behavior, and feeding rates of 2 adults (number of bites counted for $1 \mathrm{~min}$ ). At first, 20 adults were followed individually for 5 min each, with feeding activities and number of bites observed and counted, respectively. The results were found to vary little with time, and accordingly, a bite count time of 1 min was employed to expedite the surveys. Immediately after each encounter, single plankton samples were taken by quickly sweeping a portable, handle-fitted plankton net through the water at the same locality, both in the surface layer and in the water column $(3.7 \pm 0.13 \mathrm{SE} \mathrm{m}$ in depth; range 1 to $7.5 \mathrm{~m}$ ) where fish were feeding. The net had a ellipseshaped mouth $(21.5 \mathrm{~cm}$ major axis, $18.0 \mathrm{~cm}$ minor axis) and a depth of $60 \mathrm{~cm}$. A fine mesh $(0.1 \mathrm{~mm})$ was employed, because of the possibility of switching to common, smaller copepods $(<1 \mathrm{~mm}$ long) at times of low densities of larger prey. A small flowmeter fitted across the opening was rotated by the quick sweeping of the net through the water (surface layer, $54 \pm 9.5 \mathrm{SD}$ turns; feeding layer, $54 \pm 10.4 \mathrm{SD}$ turns). To reduce inconvenience in handling of collected plankton, polyethylene battles $(50 \mathrm{ml})$ with a draining window (0.1 $\mathrm{mm}$ mesh) were screwed on to the end of the net, thereby permitting the snorkeling observer to easily handle the collected plankton on the sea surface. Such a method enabled the observer to accomplish each 
survey with minimum interruptions. Because the feeding layer did not differ significantly from the surface in prey abundance (paired $t$-tests; inshore area: $t=0.661$, $\mathrm{df}=100, \mathrm{p}>0.5 ;$ offshore area: $t=0.878, \mathrm{df}=36$, p $>0.2$; data log transformed), feeding layer data only were analyzed.

Prior to the above snorkeling surveys, concurrent sampling of fish and zooplankton was undertaken on 3 July and from 5 to 21 August 1986 (a total of 6 d) at the Nishiura Bay study site. Data from 4 of 7 samplings thus made are presented in Table 5. Densities of prey individuals clearly reflected stomach fullness (Kendall's coefficient of rank correlation, $\tau=0.57, \mathrm{n}=35$, $\mathrm{p} \ll 0.001)$. Direct observations of both feeding activities and zooplankton were positively correlated with stomach fullness, suggesting that the plankton net sampled large zooplankters eaten by the fish with relative accuracy.

Continuous collections of plankton. Plankton at the surface layer was continuously collected with a suction pump from 07:00 to $19: 00 \mathrm{~h}$ on 26,27 and 29 August 1987 (during spring tides) at the Nishiura study site. This sampling period covered practically the entire diurnal activity period of adult Chromis chrysurus. The pump was based onshore and a suction hose $(25.4 \mathrm{~mm}$ inside diameter) extended $100 \mathrm{~m}$ offshore. The hose intake was fixed to within $2 \mathrm{~m}$ of the surface in a water depth of about $5 \mathrm{~m}$. The location where $C$. chrysurus aggregations were frequently detected was usually subject to measurable tidal currents. Plankton was strained with a Kitahara plankton net $(0.1 \mathrm{~mm}$ mesh), which was suspended from a tripod enabling the pump outlet hose to be inserted so as to touch the cod end of the net. Sea water was filtered at the rate of $1.9 \mathrm{~m}^{3} \mathrm{~h}^{-1}$. Cod end contents were removed 6 times per day, at $09: 00,11: 00,13: 00,15: 00,17: 00$ and 19:00 h. We also collected plankton in the vicinity of the hose intake using a portable plankton net with a flowmeter, to enable comparisons with pumped samples.

All plankton samples collected were preserved in $5 \%$ buffered formalin. The samples were split 1 to 3 times, depending on the amount of plankton, with a Motoda plankton splitter (Motoda 1959) in the laboratory. Individual items were identified to class or order under a binocular microscope, counted, and the length measured to the nearest $0.1 \mathrm{~mm}$. Copepods were further subdivided to genus. Counts were standardized by conversion to amounts per $\mathrm{m}^{3}$ of water sampled.

Statistical analyses. Data were analyzed primarily by 1 -way ANOVA, after log transformation to normalize the distribution. Homogeneity of transformed data was tested using Bartlett's test. Only in cases where variances were heterogeneous $(p<0.05)$ were

Table 1. Chromis chrysurus. Percentage composition of stomach contents by taxonomic group in volume, number and frequency of occurrence, for 92 adults collected from the Nishiura and Honmura study sites. Range of prey size consumed in each taxon is also presented. Total lengths of fish examined ranged from 150 to $195 \mathrm{~mm}$. +: values less than $0.1 \%$. Empty stomachs (33 fish) are not included in these calculations

\begin{tabular}{|c|c|c|c|c|c|}
\hline \multirow[t]{2}{*}{ Categories present } & \multirow{2}{*}{$\begin{array}{c}\text { Vol. } \\
\text { Mean \% (SE) }\end{array}$} & \multirow{2}{*}{$\begin{array}{c}\text { No. } \\
\text { Mean \% (SE) }\end{array}$} & \multirow{2}{*}{$\begin{array}{c}\text { Freq. } \\
\%\end{array}$} & \multicolumn{2}{|c|}{ Length of prey taxa } \\
\hline & & & & Measurement region & Range (mm) \\
\hline Copepoda (adults,copepodites) & $77.4(26.30)$ & $66.1(19.73)$ & 42.4 & Body length & $0.8-5.5$ \\
\hline Siphonophora (Calyconectae) & $15.1(6.73)$ & $11.7(3.08)$ & 50.0 & Nectocalyx length & $0.7-10.5$ \\
\hline Appendicularia & $1.7(0.83)$ & $8.9(5.17)$ & 37.0 & Trunk length & $0.4-2.8$ \\
\hline Chaetognatha (Sagittoidea) & $1.4(0.87)$ & $2.7(1.65)$ & 9.8 & Body length & $4.0-12.0$ \\
\hline Thaliacea & $0.7(0.32)$ & $1.7(0.72)$ & 20.7 & Body length & $1.2-8.0$ \\
\hline Pelagic fish eggs & $0.5(0.25)$ & $2.2(1.78)$ & 19.6 & Diameter & $0.6-3.7$ \\
\hline Gastropoda (pelagic type) & $0.4(0.14)$ & $1.4(0.41)$ & 28.3 & Pteropod, shell length & $0.7-3.2$ \\
\hline Polychaeta (Errantia) & $0.4(0.24)$ & $1.5(0.82)$ & 17.4 & Body length & $1.2-6.2$ \\
\hline Annelida (larvae) & $0.4(0.17)$ & $1.4(0.44)$ & 20.7 & Diameter (major axis) & $0.7-2.5$ \\
\hline Hydrozoa (except Siphonophora) & $0.2(0.16)$ & $0.1(0.03)$ & 4.3 & Diameter of exumbrella & 2.0 \\
\hline Mysidacea & + & $0.3(0.15)$ & 7.6 & Total length & $2.5-9.5$ \\
\hline Euphausiacea & + & $0.1\{0.05\}$ & 4.3 & Total length & $2.5-5.8$ \\
\hline Decapoda (Lucifer sp.) & + & + & 3.3 & Total length & $2.1-7.7$ \\
\hline Amphipoda (pelagic type) & $0.1(0.05)$ & $0.6(0.27)$ & 18.5 & Total length & $0.8-3.6$ \\
\hline Cirripedia (nauplii) & + & $0.3(0.06)$ & 12.0 & Carapace length & $0.6-1.1$ \\
\hline Copepoda (nauplii) & + & $0.1(0.11)$ & 2.2 & Body length & $0.4-0.5$ \\
\hline Ostracoda & + & $0.1(0.03)$ & 5.4 & Shell length & $0.8-1.5$ \\
\hline Cyanophyceae (Tricodesnium spp.) & + & $0.5(0.32)$ & 7.6 & & \\
\hline Amphipoda (benthic) & + & $0.1(0.05)$ & 3.3 & & \\
\hline Fish scales & $0.1(0.07)$ & $0.2(0.11)$ & 7.6 & & \\
\hline Sand grain & $\begin{array}{c}0.1(0.01) \\
+\end{array}$ & $0.1(0.08)$ & 3.3 & & \\
\hline Unidentified materials & $1.2(0.60)$ & - & 19.6 & & \\
\hline
\end{tabular}


nonparametric tests used. Parametric tests were used as often as possible, to preclude the possibility that lack of significant differences could be based on a bias dependent on the power of the statistical test.

\section{RESULTS}

\section{Stomach content analysis}

Table 1 shows the diet composition of adult Chromis chrysurus. This species is a zooplankton specialist. Almost all of the food items were planktonic animals living in the water column. In particular, planktonic copepods constituted the dominant prey, comprising $77.4 \%$ of total items by volume, $66.1 \%$ by number and $42.4 \%$ by frequency of occurrence. Gelatinous zooplankton such as siphonophores, appendicularians and chaetognaths were also important dietary components. Planktonic copepods, siphonophores, appendicularians and chaetognaths together accounted for $95.6 \%$ of the total volume and $89.4 \%$ of the total number of individuals, with the frequency of occurrence of each, except chaetognaths, exceeding $30 \%$. Thus, these 4 prey categories represented the major food of adult C. chrysurus at the study site. Only taxa distributed widely in oceanic and/or coastal waters (Yamaji 1984), as opposed to those restricted to inlet waters, were found in the stomach contents (Table 2).

The size composition of copepods occurring in the stomach contents was compared with those collected from the water column, on the basis of simultaneous collections of fish and zooplankton on 3 July and from 5 to 21 August 1986. Planktonic copepods from stomach contents comprised mainly larger individuals contributing to 3 size peaks $(3.3,2.3$ and $1.3 \mathrm{~mm})$, whereas

Table 2. Comparison of Copepoda between zooplankton patch samples and routine plankton samples in generic composition (by numerical percentage) and mean number of individuals per genus (given in parentheses). Prey densities are for individuals available in prey size (see Table 1). \#: large-sized genera, accounting for more than $1 \%$ of stomach contents. -: did not occur; + values less than $0.1 \%$; $N$ : number of samples examined or fish collected

\begin{tabular}{|c|c|c|c|c|c|c|c|}
\hline \multirow{4}{*}{ Genus } & \multicolumn{6}{|c|}{ Prey density $\left(\mathrm{m}^{-3}\right)$} & \multirow{4}{*}{$\begin{array}{c}\text { Stomach } \\
\begin{array}{c}\mathrm{N}=92 \\
\%\end{array}\end{array}$} \\
\hline & \multirow{2}{*}{\multicolumn{2}{|c|}{$\begin{array}{c}0-500 \\
N=127\end{array}$}} & \multirow{2}{*}{\multicolumn{2}{|c|}{$\begin{array}{c}500-2080 \\
N=1 \cdot 1\end{array}$}} & \multirow{2}{*}{\multicolumn{2}{|c|}{$\begin{array}{c}\text { Patches (3144-6475) } \\
\qquad N=3\end{array}$}} & \\
\hline & & & & & & & \\
\hline & $\%$ & no. & $\%$ & no. & $\%$ & no. & \\
\hline \multicolumn{8}{|l|}{ Calanoida } \\
\hline "Euchaeta & 1.9 & $(1.7)$ & 1.2 & $(11.3)$ & 2.0 & $(184.9)$ & 53.2 \\
\hline "Scolecithrix & 0.5 & $(0.4)$ & 0.7 & $(6.3)$ & 1.6 & (71.9) & 15.4 \\
\hline "Undinula & - & - & - & - & 9.7 & $(441.5)$ & 4.0 \\
\hline "Candacia & 0.9 & $(0.8)$ & - & - & - & - & 4.0 \\
\hline "Eucalanus & 20 & $(1.8)$ & 1.2 & $(10.5)$ & 5.2 & (236.3) & 2.6 \\
\hline "Nannocalanus & - & - & - & - & 0.7 & $(30.8)$ & 1.2 \\
\hline "Total & 5.3 & & 3.1 & & 21.4 & & 80.4 \\
\hline Neocalanus & & & & & & & 0.4 \\
\hline Temora & 0.5 & $(0.4)$ & - & - & - & - & 0.3 \\
\hline Calanus & - & - & - & - & 0.2 & $(10.3)$ & 0.2 \\
\hline Clausocalanus & 7.9 & (7.1) & 12.8 & $(117.1)$ & 18.2 & $(827.2)$ & 0.1 \\
\hline Lucicutia & 0.4 & (0.3) & - & - & - & - & 0.1 \\
\hline Pontellina & 0.4 & $(0.4\}$ & - & - & - & - & 0.1 \\
\hline Pleuromamma & & & & & & & 0.1 \\
\hline Acrocalanus & 4.0 & (3.5) & 5.7 & $(51.9)$ & 3.7 & $(169.5)$ & + \\
\hline Rhincalanus & & & & & & & + \\
\hline Calocalanus & 2.4 & $(2.1)$ & - & - & 0.9 & $(41.1)$ & + \\
\hline Paracalanus & 11.0 & $(10.0)$ & 11.3 & $(102.7)$ & 12.8 & $(579.5)$ & - \\
\hline Acartia & 1.9 & $(1.7)$ & 1.7 & $(15.4)$ & 2.5 & (112.9) & - \\
\hline Centropages & 0.3 & $(0.3)$ & - & - & 0.9 & $(41.1)$ & - \\
\hline Mecynocera & - & - & - & - & 0.5 & $(20.5)$ & - \\
\hline Calanoida spp. & 8.7 & $(7.7)$ & 11.6 & $(105.6)$ & 1.4 & $(65.7)$ & + \\
\hline \multicolumn{8}{|l|}{ Cyclopoida } \\
\hline Oncaea & 16.7 & $(14.9)$ & 26.8 & $(244.4\}$ & 23.7 & $(1074.9)$ & 13.5 \\
\hline Corycaeus & 8.9 & (7.9) & 10.3 & $(93.7)$ & 4.3 & (195.1) & 2.9 \\
\hline Sapphirina & - & - & - & - & 0.9 & $(41.1)$ & 1.3 \\
\hline Copilia & - & - & - & - & 0.2 & $(10.3)$ & 0.1 \\
\hline Oithona & 21.7 & $(19.3)$ & 11.2 & $(102.5)$ & 4.2 & $(189.9)$ & + \\
\hline \multicolumn{8}{|l|}{ Harpacticoida } \\
\hline Macrosetella & 4.7 & $(4.2)$ & 4.3 & $(39.4)$ & 3.5 & $(159.2)$ & 0.3 \\
\hline Clytemnestra & 0.6 & $(0.5)$ & - & - & - & - & + \\
\hline Harpacticoida spp. & 3.7 & (3.3) & 1.2 & $(11.0)$ & 0.7 & $(30.8)$ & - \\
\hline
\end{tabular}


those available from the water column were dominated by much smaller individuals, less than $0.8 \mathrm{~mm}$ long (Median test, $\chi^{2}=1943.98, \mathrm{df}=1, \mathrm{p} \ll 0.001$ ).

\section{Densities of prey individuals}

Data on zooplankton densities and foraging behavior were subdivided into 2 groups (inshore and offshore) along the observation course, according to water depth and the possibility of exchange of adult fishes between aggregations. This enabled the recording of any differences in zooplankton density and foraging behavior between the 2 areas. The densities of prey in the water column were expressed as those of the sum of prey-sized individuals available within each category (corresponding to size ranges found in stomachs; see Table 1), and are hereafter referred to as 'prey individuals'.

Fig. 2 indicates the frequency distribution of densities of prey individuals in midwater feeding grounds at locations where aggregations of adult fishes were found. Both in the inshore and offshore area, con-

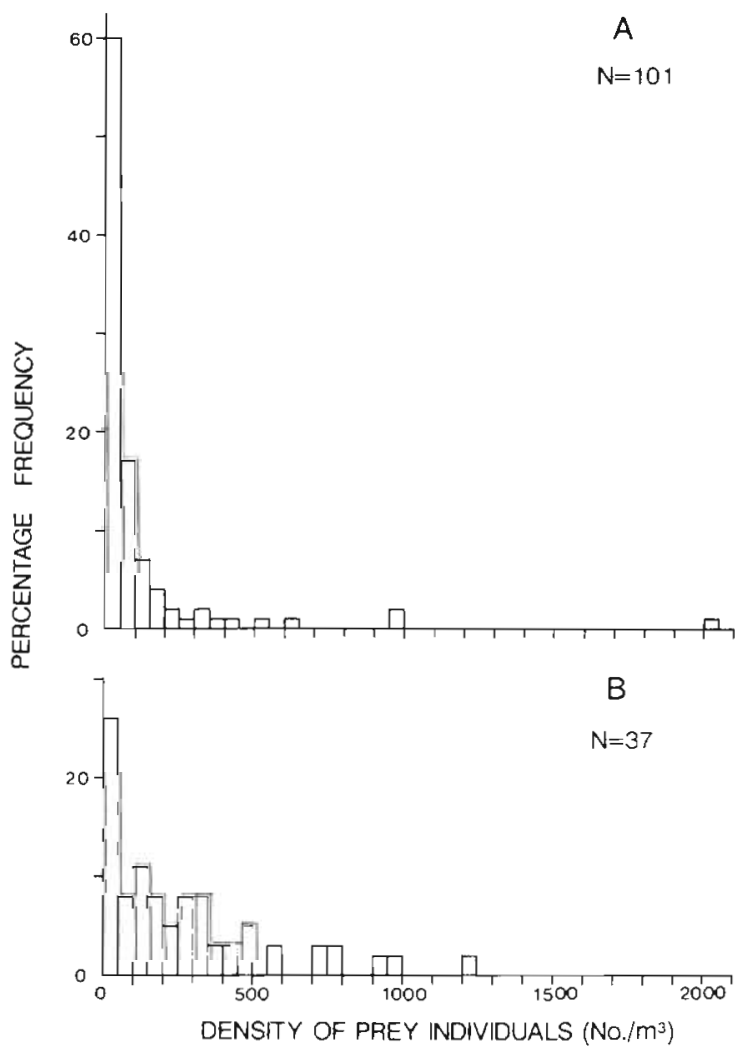

Fig. 2. Frequency distribution of densities of prey individuals (see Table 1 ) at stations where aggregations of Chromis chrysurus engaged in particulate-feeding. Plankton sampling was conducted with a portable net along the snorkeling course at the Nishiura Bay study site. (A) Inshore area

$(B)$ offshore area. N: number of samples examined siderably lower densities (less than $50 \mathrm{~m}^{-3}$ ) occurred with high frequency, whereas densities of more than $500 \mathrm{~m}^{-3}$ occurred with extremely low frequency. Thus it was found that adult Chromis chrysurus would frequently be exposed to few prey individuals. Diurnal differences in densities of prey individuals were undetectable (1-way ANOVAs; inshore: $F=27.43$, df $=$ 5.95, p > 0.05; offshore: $F=9.73, \mathrm{df}=5,31, \mathrm{p} \gg 0.25$ ), as were differences among 4 classes of tide ranges (Table 3; 1 -way ANOVAs; inshore: $F=6.57$, df $=2,91$, $p \gg 0.25$, tested together, except for the $>200 \mathrm{~cm}$ tide range class; offshore: $F=2.12, \mathrm{df}=3.33, \mathrm{p} \gg 0.25$ ). Differences in prey density among days, therefore, were not confounded by short-term changes in abundance at different times of a day and differences in abundance among tidal cycles. In contrast, differences among the inshore surveys of prey individuals were significant (Kruskal-Wallis tests; inshore: $H_{\text {cor }}=62.01$, df $=35, p<0.01$; of fshore: $H_{\text {cor }}=26.46$, df $=23, p>0.2$ ); those among the offshore surveys would also have been significant if a larger sample size had been obtained. Plankton sampling with a pump was conducted at spring tide (Table 4), when it seemed most probable that prey individuals would be collected more abundantly, in particular during flood and ebb tide, because of the effect of tidal currents (see the section 'Study site'). We found, however, that extremely low densities of available prey individuals characterized almost the whole of the diurnal active period of adult Chromis chrysurus, which ranges from dawn to dusk. The trend was compatible with that of plankton collections using the portable net in the vicinity of the hose intake, although the water sampling velocity of the pump may not have been sufficient to sample highly mobile zooplankters. The results obtained by the pump equipment used do not overcome the objection that avoidance of mobile zooplankters could have been a problem with our sampling technique and thus further work is required to properly understand the relation of tidal cycles to food supplies. However, these results at least suggested that food availability can be limited, even at spring tide, when tidal currents are usually relatively strong.

Fortunately, we were able to sample zooplankton patches, appearing as densely aggregated zooplankton in the surface layer, on 2 occasions: 21 August 1986 (2 samples) at the Nishiura study site and 19 October 1986 (1 sample) in Honmura Bay. Such patches could be clearly recognized with the naked eye. Although zooplankton patches were observed several times, it was only on the above days that samples could be collected. Densities of prey individuals (3144 to 6475 ind $\mathrm{m}^{-3}$ ) in the zooplankton patches were much higher than those $\left(0\right.$ to $2080 \mathrm{~m}^{-3}$ ) in samples taken during the snorkeling surveys. The size composition of 
Table 3. Prey densities (for prey individuals), and Chronis chrysurus feeding rates and stomach fullness stratified according to 4 classes of tide range. Values of prey densities and feeding rates are based on data obtained by the snorkeling surveys. Values are presented as mean \pm standard error, with ranges given in parentheses. N: total number of plankton samples, field observations of feeding behavior or fish collected

\begin{tabular}{|c|c|c|c|c|c|}
\hline \multirow[t]{2}{*}{ Tide range $(\mathrm{cm})$} & \multicolumn{2}{|c|}{ Prey density $\left(\mathrm{m}^{-3}\right)$} & \multicolumn{2}{|c|}{ Feeding rate } & \multirow[t]{2}{*}{ Stomach fullness } \\
\hline & Inshore & Offshore & Inshore & Offshore & \\
\hline$<100$ & $\begin{array}{c}88.2 \pm 40.1 \\
(0-998.8) \\
N=25\end{array}$ & $\begin{array}{c}313.1 \pm 98.7 \\
(0-792.5) \\
N=10\end{array}$ & $\begin{array}{c}1.0 \pm 0.4 \\
(0-8) \\
N=26\end{array}$ & $\begin{array}{l}3.6 \pm 0.9 \\
(0-9.5) \\
N=17\end{array}$ & $\begin{array}{c}1.04 \pm 0.26 \\
(0-6.38) \\
N=36\end{array}$ \\
\hline $100-150$ & $\begin{array}{c}91.7 \pm 26.5 \\
(0-409.4) \\
N=24\end{array}$ & $\begin{array}{c}229.9 \pm 95.7 \\
(0-943.3) \\
N=9\end{array}$ & $\begin{array}{c}1.9 \pm 0.6 \\
(0-10) \\
N=29\end{array}$ & $\begin{array}{c}3.7 \pm 1.4 \\
(0-16) \\
N=14\end{array}$ & $\begin{array}{c}1.84 \pm 0.55 \\
(0-17.88) \\
N=41\end{array}$ \\
\hline $150-200$ & $\begin{array}{c}117.9 \pm 57.7 \\
(0-2080.1) \\
N=45\end{array}$ & $\begin{array}{c}213.3 \pm 55.2 \\
(0-603) \\
N=12\end{array}$ & $\begin{array}{c}2.6 \pm 0.6 \\
(0-19) \\
N=58\end{array}$ & $\begin{array}{l}5.4 \pm 1.6 \\
(0-17) \\
N=15\end{array}$ & $\begin{array}{c}1.18 \pm 0.49 \\
(0-10.53) \\
N=29\end{array}$ \\
\hline$>200$ & $\begin{array}{c}18.1 \pm 9.2 \\
(0-56.6) \\
N=8\end{array}$ & $\begin{array}{c}345.0 \pm 174.9 \\
(0-1155.9) \\
N=6\end{array}$ & $\begin{array}{l}0.1 \pm 0.1 \\
(0-1.5) \\
N=12\end{array}$ & $\begin{array}{c}6.7 \pm 2.8 \\
(0-22) \\
N=9\end{array}$ & $\begin{array}{c}2.88 \pm 1.07 \\
(0-15.27) \\
N=26\end{array}$ \\
\hline
\end{tabular}

the zooplankton patches was compared with that of the snorkeling survey samples (Fig. 3). Whereas copepods less than $1 \mathrm{~mm}$ long in the latter comprised a large proportion of the total number, in zooplankton patches these were reduced in proportion, and a size peak of around $3 \mathrm{~mm}$ was conspicuous, thus exhibiting a considerable increase in large copepods (Median test; $\chi^{2}=$ $602.12, \mathrm{df}=1, \mathrm{p} \ll 0.001$ for patches $\mathrm{vs}$ samples of $<500 \mathrm{~m}^{-3} ; \chi^{2}=1044.20, \mathrm{df}=1, \mathrm{p} \ll 0.001$ for patches $v \mathrm{~s}$ samples of 500 to $2080 \mathrm{~m}^{-3}$ ). The other major prey taxa, lumped together, showed a similar trend (Fig. 3; Median test; $\chi^{2}=25.06, \mathrm{df}=1, \mathrm{p}<0.001$ for patches vs samples of $<500 \mathrm{~m}^{-3} ; \chi^{2}=10.33$, df $=1, \mathrm{p}<0.01$ for

Table 4. Temporal changes in density (no. $\mathrm{m}^{-3}$ ) of prey individuals (see Table 1 caption) collected with a pump over almost the whole of the diurnal active period of Chromis chrysurus. Data for collections sampled by the portable net are given in parentheses. Tide time and height are also given

\begin{tabular}{|c|c|c|c|c|c|c|}
\hline $\begin{array}{l}\text { Sampling time } \\
\text { (h) }\end{array}$ & \multicolumn{2}{|c|}{$\begin{array}{c}\text { e } 26 \text { Aug } \\
1987\end{array}$} & \multicolumn{2}{|c|}{$\begin{array}{l}27 \text { Aug } \\
1987\end{array}$} & \multicolumn{2}{|c|}{$\begin{array}{l}29 \mathrm{Aug} \\
1987\end{array}$} \\
\hline $07: 00-09: 00$ & \multicolumn{2}{|c|}{8.4} & 25.3 & $(12.3)$ & \multicolumn{2}{|c|}{4.2} \\
\hline $09: 00-11: 00$ & \multicolumn{2}{|c|}{12.6} & 8.4 & $(0)$ & \multicolumn{2}{|c|}{0} \\
\hline $11: 00-13: 00$ & \multicolumn{2}{|c|}{0} & & (0) & \multicolumn{2}{|c|}{0} \\
\hline $13: 00-15: 00$ & \multicolumn{2}{|c|}{0} & 0 & (0) & \multicolumn{2}{|c|}{0} \\
\hline $15: 00-17: 00$ & \multicolumn{2}{|c|}{4.2} & 0 & $(0)$ & \multicolumn{2}{|c|}{0} \\
\hline $17: 00-19: 00$ & \multicolumn{2}{|c|}{4.2} & 0 & $(0)$ & \multicolumn{2}{|c|}{0} \\
\hline Tide & $\begin{array}{l}\text { Time } \\
\text { (h) }\end{array}$ & $\begin{array}{l}\mathrm{Ht} \\
(\mathrm{cm})\end{array}$ & $\begin{array}{l}\text { Time } \\
\text { (h) }\end{array}$ & $\begin{array}{c}\mathrm{Ht} \\
(\mathrm{cm})\end{array}$ & $\begin{array}{l}\text { Time } \\
\text { (h) }\end{array}$ & $\begin{array}{l}\mathrm{Ht} \\
(\mathrm{cm})\end{array}$ \\
\hline Low & 01:48 & 91 & $02: 17$ & 83 & $03: 22$ & 171 \\
\hline High & $07: 48$ & 244 & $08: 21$ & 241 & $09: 32$ & 224 \\
\hline Low & $14: 08$ & 45 & $14: 35$ & 54 & $15: 32$ & 83 \\
\hline High & $20: 24$ & 241 & $20: 47$ & 242 & $21: 36$ & 237 \\
\hline
\end{tabular}

patches vs those of 500 to $2080 \mathrm{~m}^{-3}$ ). The generic composition of copepods is given in Table 2 . Compared with the snorkeling survey samples, zooplankton patches were characterized by a high percentage of large-sized oceanic genera (i.e. Euchaeta, Scolecithrix, Undinula, Eucalanus, Nannocalanus), which, together with Candacia, made up over $80 \%$ of Chromis chrysurus stomach contents. Although an oceanic genus, Candacia was not found in the zooplankton patches from which samples were obtained.

\section{Feeding behavior and stomach fullness}

Feeding rates were directly related to densities of prey individuals in the water column (Fig. 4; Kendall's coefficient of rank correlation; $\tau=0.650, \mathrm{n}=165, \mathrm{p} \ll$ 0.001). Feeding behavior itself changed in almost all individuals of aggregations, from aimless meandering to active, 'up-and-down' searching following an increase in densities of prey individuals (Fig. 4). Often adult Chromis chrysurus became stationary at times of low prey densities, seemingly as if waiting for drifting zooplankton to be transported inshore. The frequency distribution of feeding rates (number of bites per min) was asymmetrical, being extremely skewed to the left (chi-square tests; inshore: $\chi^{2}=915.05$, df $=19, \mathrm{p} \ll$ 0.001 ; offshore: $\chi^{2}=76.36$, df $=7, p \ll 0.001$ ). That is, low feeding rates occurred frequently and periods of restricted feeding were readily observed. On the other hand, high feeding rates did not occur often, and active feeding was infrequently observed. Diurnal differences in feeding rates were undetectable (1-way ANOVAs; inshore: $F=5.90, \mathrm{df}=5,119, \mathrm{p}>0.05$; offshore: $F=2.38, \mathrm{df}=5,49, \mathrm{p} \gg 0.25$ ), as were differences 


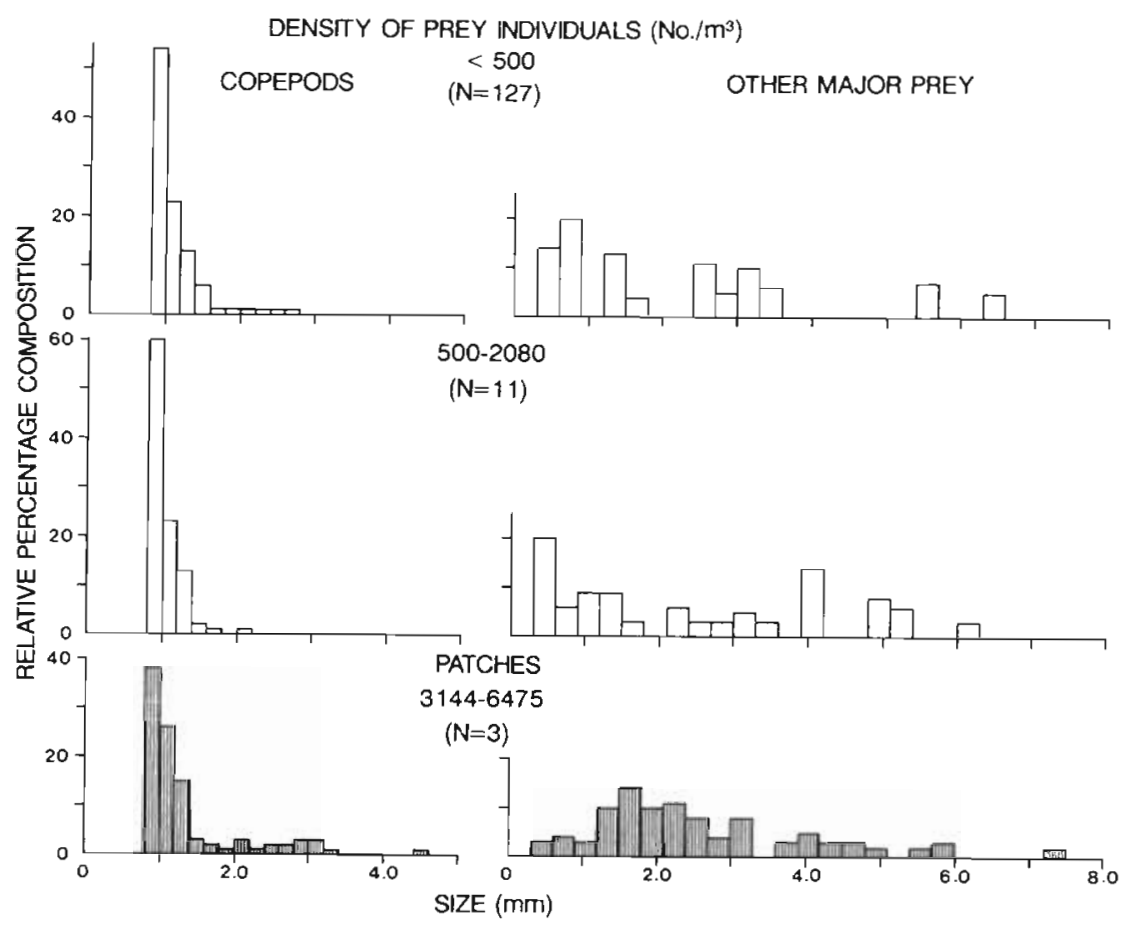

Fig. 3. Comparison of size-frequency distributions of major prey individuals in plankton samples collected both during observations of feeding behavior along the snorkeling course at the Nishiura Bay study site and from separate samples. Siphonophores, appendicularians and chaetognaths are lumped together as 'other major prey'. $\mathrm{N}$ : number of samples examined

among 4 classes of tide ranges (Table 3; 1-way ANOVA; inshore: $F=1.52, \mathrm{df}=2,110, \mathrm{p} \gg 0.25$; offshore: $F=0.31$, df $=3,51, p \gg 0.25$ ). In contrast, differences in feeding rates among the surveys were significant (Kruskal-Wallis tests; inshore: $H_{\text {cor }}=71.05$, df $=$ 35, $\mathrm{p}<0.001$; offshore: $\left.H_{\text {cor }}=35.85, \mathrm{df}=23, \mathrm{p}<0.05\right)$.

Such a trend in feeding intensity was reflected in stomach fullness. Values of stomach fullness were plotted within each sampling month from June to October (Fig. 5). Stomach fullness within any month frequently showed remarkably low values and empty stomachs were found in a high proportion (31 to $59 \%$ ) of the fishes examined, although significant seasonal variation was detected (1-way ANOVA; $F=4.60, \mathrm{df}=$ $4,134, \mathrm{p}<0.005)$. The relationship between stomach fullness and collecting times was compared between means of total specimens pooled over the entire period and those of specimens collected on 23 October 1986 (Fig. 6). The 2 diurnal patterns differed markedly from each other in stomach fullness, suggesting that a

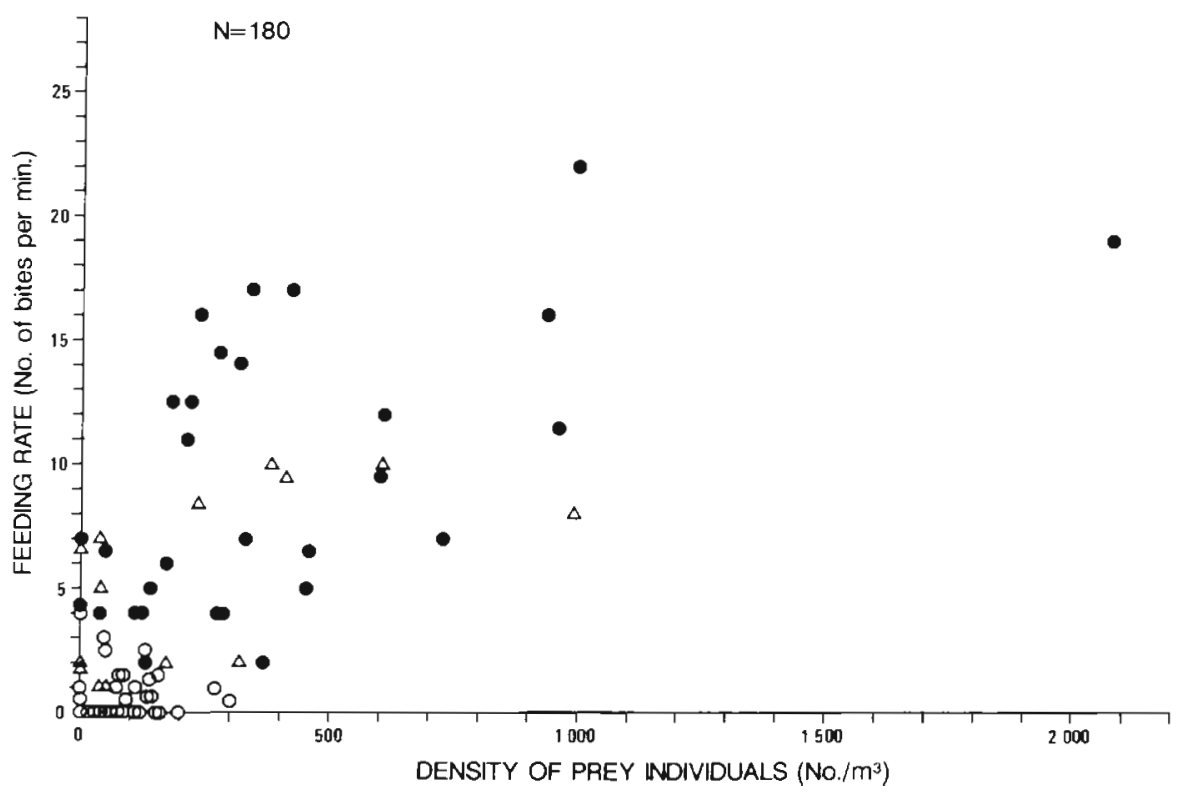

\author{
Aimless meandering \\ "Up-and-down" searching \\ $\triangle$ Intermediate state between \\ the above feeding behaviors
}

Fig. 4. Chromis chrysurus. Relationship between densities of prey individuals (see Table 1) at stations where aggregations of $C$. chrysurus engaged in particulate-feeding at the Nishiura Bay study site and feeding rates number of bites $\left.\min ^{-1}\right)$. N: number of plankton samples examined 


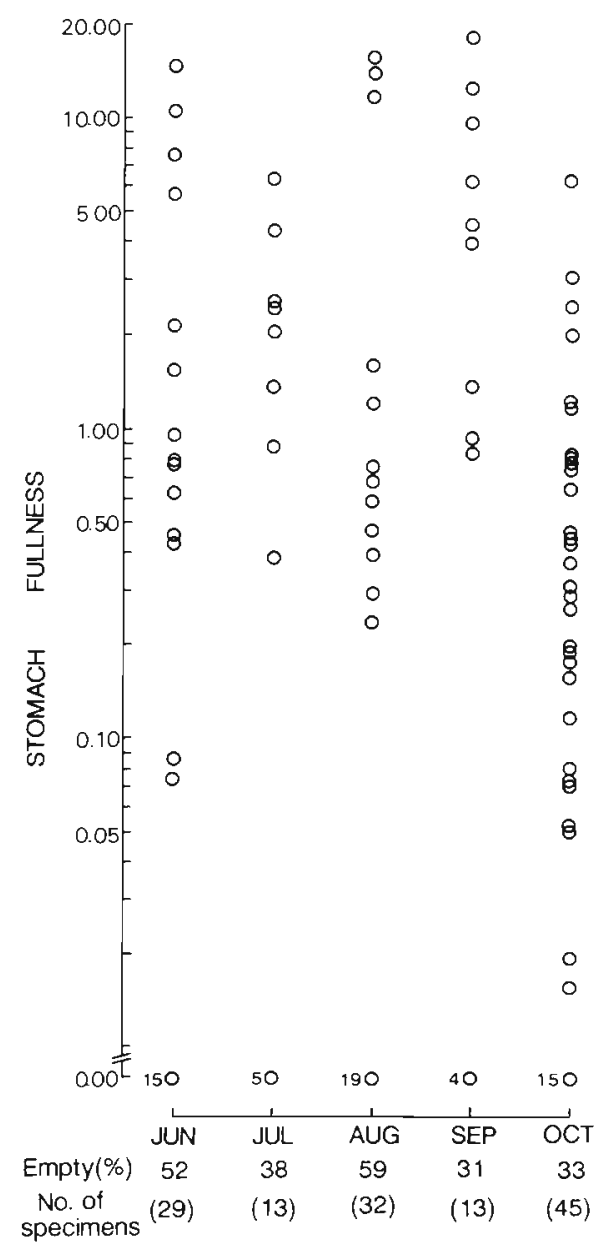

Fig. 5. Chromis chrysurus. Distribution of stomach fullness values and sampling month, for 132 adults collected from Nishiura and Honmura Bays. Stomach fullness is defined in the text. Numerals accompanying some circles indicate multiple records. Note log scale

definite daily periodicity in feeding was lacking. Furthermore, differences among 4 tide range classes were undetectable (Table 3; 1 -way ANOVA; $F=1.27$, $\mathrm{df}=3,128, \mathrm{p} \gg 0.25)$, and stomach fullness was highly consistent with prey densities in the water column, irrespective of tidal cycles and water currents (Table 5).

In contrast, significant differences in stomach fullness among sets of specimens sampled together were detected within each sampling month from June to October (Kruskal-Wallis tests; June: $H_{\text {cor }}=18.46$, df $=8, p<0.02 ;$ July: $H_{\text {cor }}=9.07$, df $=2, p<0.02$; August: $H_{\text {cor }}=19.20, \mathrm{df}=8, \mathrm{p}<0.02$; September: $H_{\text {cor }}=$ 12.17, $\mathrm{df}=3, \mathrm{p}<0.01 ;$ October: $H_{\text {cor }}=25.70, \mathrm{df}=10$, $\mathrm{p}<0.01$ )

A change in the size composition of each major prey category in the stomach contents, with increase in stomach fullness, is indicated in Fig. 7. Stomach fullness was divided into 3 categories, according to the

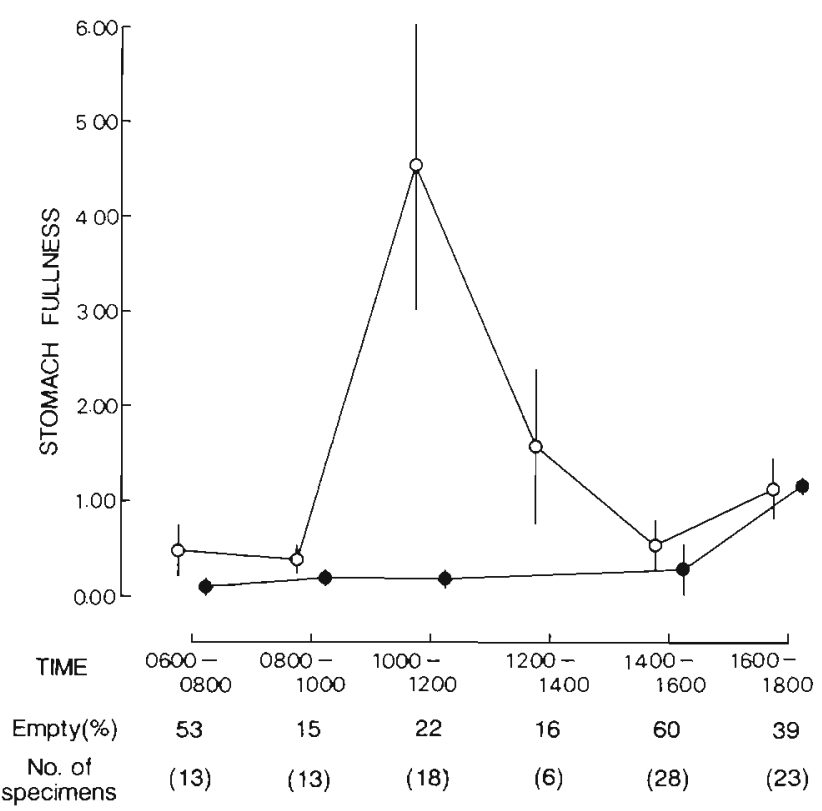

Fig. 6. Chromis chrysurus. Relationship between stomach fullness values and collecting times, compared between means of total specimens $(\mathrm{N}=101)$ pooled through the entire period and of those collected on 23 October $1986(\mathrm{~N}=27)$. Stomach fullness is defined in the text. Vertical bars represent $1 \mathrm{SE}$. Detailed sampling times for the specimens on 23 October 1986 are indicated in the text. (0) All specimens; (•) specimens taken on 23 October 1986

degree of swelling of the stomach: $<1.00$ (almost no feeding), 1.00 to 5.00 (moderate feeding), >5.00 (intensive feeding). The size composition of prey items was then compared between the 3 categories of stomach fullness. When stomachs were filled with food $(>5.00)$, large-sized copepods with a mode of about $3.3 \mathrm{~mm}$ were found in considerably higher proportions (Median test; $\chi^{2}=1553.11$, df $=2, p \ll 0.001$ ). The other prey items also tended to increase in size (Median test; $\chi^{2}=$ $23.78, \mathrm{df}=2, \mathrm{p} \ll 0.001$ for siphonophores, $x^{2}=28.08$ $\mathrm{df}=2, \mathrm{p} \ll 0.001$ for appendicularians). In particular, chaetognaths, which are usually large, oceanic zooplankters, were not found in the lowest category $(<1.00)$. It was clear that the highest and lowest categories of stomach fullness in Chromis chrysurus were characterized by substantial differences in size composition of major prey, and that no fully fed condition had resulted from the utilization of zooplankton communities at times of low prey densities in the water column.

At Kuchinoerabu Island the species seems to initiate nesting from the end of October at Kuchinoerabu Island (gonad somatic index; June to September: male-max $0.34 \pm 0.03 \mathrm{SE}$, $\min 0.26 \pm 0.02 \mathrm{SE}, \mathrm{n}=45$, female-max $0.96 \pm 0.15 \mathrm{SE}, \min 0.54 \pm 0.03 \mathrm{SE}, \mathrm{n}=43$; beginning of October: male $1.92 \pm 0.25 \mathrm{SE}, \mathrm{n}=5$, female $2.68 \pm 0.75 \mathrm{SE}, \mathrm{n}=3$; end of October: male 
Table 5. Chromis chrysurus. Four individual cases at neap and spring tide taken from concurrent samplings of fish and zooplankton, with observations of feeding behavior. Values of stomach fullness, prey densities (for prey individuals) and feeding rates indicate mean values (standard error given in parentheses). N: number of plankton samples, fish collected or fish observed.

A: inshore area, B: offshore area at the Nishiura Bay study site (see Fig. 1)

\begin{tabular}{|c|c|c|c|c|c|c|}
\hline $\begin{array}{l}\text { Tide range } \\
\qquad(\mathrm{cm})\end{array}$ & Date & Place & $\begin{array}{l}\text { Observation of zooplankton } \\
\text { with the naked eye, and } \\
\text { water currents }\end{array}$ & $\begin{array}{l}\text { Stomach } \\
\text { fullness }\end{array}$ & $\begin{array}{l}\text { Prey } \\
\text { density } \\
\left(\mathrm{m}^{-3}\right)\end{array}$ & Feeding behavior \\
\hline \multicolumn{7}{|l|}{ Neap tide } \\
\hline 68 & 3 Jul 1986 & A & $\begin{array}{l}\text { A rapid increase of zoo- } \\
\text { plankton found, together } \\
\text { with a SW current }\end{array}$ & $\begin{array}{l}3.54 \\
(0.81) \\
N=5\end{array}$ & $\begin{array}{l}951.1 \\
N=1\end{array}$ & $\begin{array}{l}\text { Up-and-down searching } \\
\text { No. of bites uncounted }\end{array}$ \\
\hline 110 & 12 Aug 1986 & $B$ & $\begin{array}{l}\text { No observed increase of } \\
\text { zooplankton. } \\
\text { Current not measured }\end{array}$ & $\begin{array}{l}0.17 \\
(0.11) \\
N=6\end{array}$ & $\begin{array}{c}28.9 \\
(2.4) \\
\mathrm{N}=3\end{array}$ & $\begin{array}{l}\text { Close to aimless meandering } \\
3.8 \text { (1.3) bites } \mathrm{min}^{-1}, \mathrm{~N}=5\end{array}$ \\
\hline \multicolumn{7}{|l|}{ Spring tide } \\
\hline 207 & 6 Aug 1986 & A & $\begin{array}{l}\text { No observed increase of } \\
\text { zooplankton. } \\
\text { NNE current }\end{array}$ & $\begin{array}{l}\text { Empty } \\
N=6\end{array}$ & $\begin{array}{l}35.7 \\
(22.9) \\
N=5\end{array}$ & $\begin{array}{l}\text { Aimless meandering } \\
0.5(0.5) \text { bites } \text { min }^{-1}, N=6\end{array}$ \\
\hline 227 & 21 Aug 1986 & A & $\begin{array}{l}\text { Densely aggregated zoo- } \\
\text { plankton patches, including } \\
\text { large-sized zooplankters, } \\
\text { covered the inshore area. } \\
\text { No discernible current }\end{array}$ & $\begin{array}{l}13.53 \\
(0.77) \\
N=4\end{array}$ & $\begin{array}{c}4810.4 \\
(1666.0) \\
N=2\end{array}$ & $\begin{array}{l}\text { Typical up-and-down } \\
\text { searching. Actively } \\
\text { feeding while moving } \\
\text { around } \\
21(0.6) \text { bites } \text { min }^{-1}, \mathrm{~N}=3\end{array}$ \\
\hline
\end{tabular}

$6.53 \pm 0.40 \mathrm{SE}, \mathrm{n}=23$, female $8.32 \pm 0.80 \mathrm{SE}, \mathrm{n}=16$ ) In October, males and females were almost equal with regard to proportion of empty stomachs (male $33 \%$, $\mathrm{n}=27$; female $34 \%, \mathrm{n}=18$ ). Colonial nesting was not observed during the snorkeling surveys and free swimming fishes only were collected. For these reasons, we considered that there were no direct effects of breeding activities on the feeding of adults during the period examined.

\section{DISCUSSION}

The results of this study show that at Kuchinoerabu Island zooplankton patches including a great number of prey occur after long intervals of low prey densities. Patches are, therefore, most important as a food resource, and furthermore their value is not only quantitatively but also qualitatively enhanced because they include a variety of large-sized zooplankters. A similar

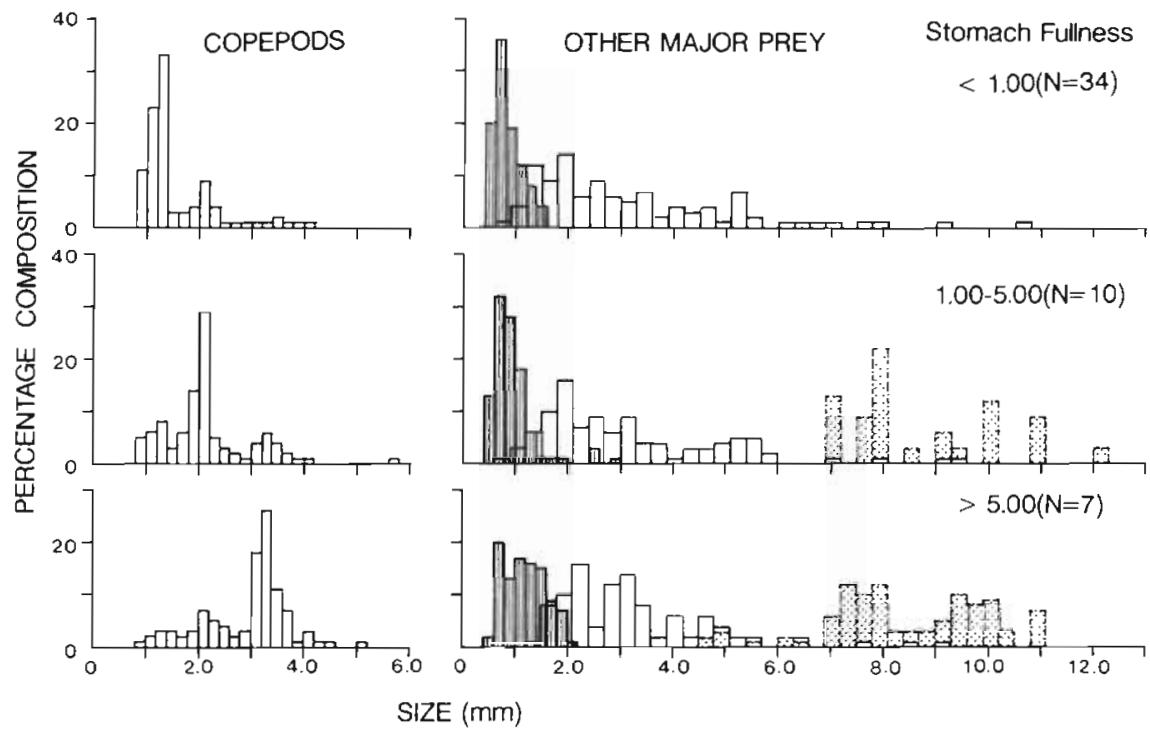

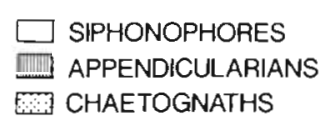

Fig. 7. Chromis chrysurus. Degree of satiation and size-distribution of major prey categories found in the stomach contents of 51 adults (empty stomachs not considered) collected from Nishiura and Honmura Bays. Stomach fullness, defined in the text, was divided into the following 3 categories, according to the degree of swelling: < 1.00 , almost no feeding: 1.00 to 5.00 , moderate feeding; $>5.00$, intensive feeding. $N$ : number of fish examined 
pattern in zooplankton prey size was suggested by Tribble \& Nishikawa (1982). They compared the diets of 4 planktivorous damselfishes (genus Chromis), examining size and type of prey items. Significant differences were found in the average size of ingested zooplankters on different sampling days, independent of fish species. They presumed that such differences between sampling days reflected temporal changes in the overall zooplankton community, but did not examine prey densities in the water column. We infer that such changes in zooplankton community would be caused by occurrence of patches.

An ongoing period of food unavailability raises the possibility that adult Chromis chrysurus might well take behavioral action to procure food. In comparison, the omnivorous pomacentrid fish Abudefduf vaigiensis, which feeds principally on zooplankters, supplements a food shortage by switching to benthic, filamentous algae at times of low densities of pelagic copepods, its favorite prey (Noda et al. 1990). Larger species of Chromis, specializing in zooplankton feeding, are known to migrate considerable distances daily to the incurrent end of the home range from their nocturnal shelter sites and to forage there (Bray 1981, Kingsford \& MacDiarmid 1988). Similar foraging movements and response to tidal currents were observed for a local population of adult $C$. chrysurus in the inshore area (unpubl.). Such an extensive home range is generally considered to relate to the procurement of food at low prey density. However, these species do not forage throughout the home range but swim directly to feeding sites. At the feeding sites, C. chrysurus assumed a state close to resting (Fig. 4, Table 5), rather than searching actively for prey, at times of low prey densities. Consequently, it is unlikely that an extensive home range permits steady harvesting of prey.

On the other hand, investigations on site-attached fishes emphasized that the velocity of water currents is important to feeding intensity of these fishes (Stevenson 1972, Popper \& Fishelson 1973, de Boer 1978, Thresher 1983). Despite low prey densities, high current velocities might permit adult Chromis chrysurus to increase its food intake because of the faster rate of replenishment of zooplankton. However, on several occasions of low prey densities, we observed that the feeding rates of adult $C$. chrysurus under strong current flows were as low as those under weak flows (Table 5; Noda et al. unpubl.), suggesting that feeding rates are regulated more by prey density than by current velocity.

It could be argued that adult Chromis chrysurus may switch to common, smaller copepods less than $0.8 \mathrm{~mm}$, as shown in 'Results', and/or ones swarming near the bottom during the day (e.g. Emery 1968, Hamner \&
Carleton 1979, Ueda et al. 1983, Tanaka et al. 1987a, Kimoto \& Nakashima 1988). First, switching to smaller ones seems unlikely for adult $C$. chrysurus, which does not take copepods less than $0.8 \mathrm{~mm}$ long. Next, it has been reported that swarming copepods are utilized as prey by some juvenile, demersal fishes, such as red sea bream, gobioids, and Japanese grunt and sand eels (Sekiguchi 1978, Matsumiya et al. 1980, Matsumiya \& Takahashi 1983, Tanaka et al. 1987b). At Kuchinoerabu Island 2 species of swarming copepods (Oithona oculata and Tortanus erabuensis) have been detected (Ohtsuka et al. 1987, Noda unpubl.). However, no swarming copepods were found in the stomach contents of adult C. chrysurus, only drifting copepods that had originated offshore (Table 2). Swarming copepods near the bottom, therefore, seem to be unutilized by adult $C$. chrysurus. In conclusion, food intake by $C$. chrysurus appears to be insufficient by any means in a state of low prey densities, and thus adult $C$. chrysurus must be subject to extreme food deprivation.

This may also explain the lack of daily periodicity in feeding rates and stomach fullness. Even though prey densities were low over the diurnal active period of Chromis chrysurus, a constant acquisition of prey would eventually lead to satiation. Hence both active feeding and inactive periods would be expected, but this was not the case. Daily periodicity in feeding of planktivorous reef fishes has been reported in a few studies (Fricke 1970, Stevenson 1972). However, extreme shortages of food may constrain adult C. chrysurus to concentrate on foraging when feeding conditions are favorable, according to the spatial heterogeneity of zooplankton communities. Accordingly, we infer that the species depends greatly on zooplankton patches for its food supply at Kuchinoerabu Island.

From this point of view, foraging behavior of adult Chromis chrysurus may be unilaterally determined by the frequency of occurrence of zooplankton patches and there seems to be no room for any positive measures to stabilize the daily amount of ingested zooplankton prey. On the other hand, adult $C$. chrysurus may store fat in the body by feeding intensely on densely aggregated zooplankters, thereby accumulating sufficient food overall. In this case, the significance of food deprivation at low prey densities would hinge on the frequency with which the fish encountered zooplankton patches. Hence, adult C. chrysurus would need the behavioral ability to efficiently locate zooplankton patches.

Our studies have demonstrated the fundamental importance of zooplankton patches in the foraging of adult Chromis chrysurus. To elucidate adaptive aspects of foraging behavior of adult $C$. chrysurus in terms of efficient utilization of zooplankton patches, we need to understand the hydrographic and/or 
biological forces causing zooplankton prey to be aggregated into patches. If these patches originate from fronts resulting from the interaction of tidal currents and topography (e.g. Wolanski \& Hamner 1988, Kingsford et al. 1991), they would occur in all seasons. By contrast, if patches are mostly attributed to Langmuir circulation and/or a coastal upwelling front (e.g. Hamner \& Schneider 1986, Hobson \& Chess 1988 ), which are produced by winds, their frequency would vary with season. These are merely examples of possible forces, and it is essential that the pattern of occurrence of patches should be understood, either as short-term processes only or as seasonal processes. An understanding of hydrographic and/or biological forces would show also whether or not the occurrence of large-sized zooplankters in the examined patches represents the usual situation or results from some occasional cause. Clarification of these points would help elucidate adaptive foraging behavior of planktivorous reef fishes such as $C$. chrysurus.

Acknowledgments. We are grateful to Dr S. Ohtsuka of Hiroshima University, for identification of zooplankton, Dr Y. Yanagisawa of Ehime University, for critical reading of the manuscript, and to the people of Kuchinoerabu Island, for permission to work in their waters. Comments and suggestions of anonymous reviewers were also very helpful in revising the manuscript. I also thank Dr G. S. Hardy for his help in correcting the English.

\section{LITERATURE CITED}

Bray, R. N. (1981). Influence of water currents and zooplankton densities on dajly foraging movements of blacksmith, Chromis punctipinnis, a planktivorous reef fish. Fish. Bull. U.S. 78: 829-841

Bray, R. N., Miller, A. C., Geesey, G. G. (1981). The fish connection: a trophic link between planktonic and rocky reef communities? Science 214: 204-205

Bray, R. N., Purcell, L. J., Miller, A. C. (1986). Ammonium excretion in a temperate-reef community by a planktivorous fish, Chromis punctipinnis (Pomacentridae), and potential uptake by young giant kelp, Macrocystis pyrifera (Laminariales). Mar. Biol. 90: 327-334

Brock, R. E., Lewis, C., Wass, R. C. (1979). Stability and structure of a fish community on a coral patch reef in Hawaii. Mar. Biol. 54: 281-292

Coates, D. (1980). Prey-size intake in humbug damselfish, Dascyllus aruanus (Pisces, Pomacentridae) living within social groups. J. Anim. Ecol. 49: 335-340

de Boer, B. A. (1978). Factors influencing the distribution of the damselfish Chromis cyanea (Poey), Pomacentridae, on a reef at Curaçao, Netherlands Antilles. Bull. mar. Sci. 28: $550-565$

Emery, A. R. (1968). Preliminary observations on coral reef plankton. Limnol. Oceanogr. 13: 293-303

Fishelson, L., Popper, D., Avidor, A. (1974). Biosociology and ecology of pomacentrid fishes around the Sinai Peninsula (northern Red Sea). J. Fish Biol. 6: 119-133

Fishelson, L (1977). Sociobiology of feeding behavior of coral fish along the coral reef of the Gulf of Elat (= Gulf of 'Aqaba), Red Sea. Israel J. Zool. 26: 114-134

Fitch, W. I S., Shapiro, D. Y (1990). Spatial dispersion and nonmigratory spawning in the bluehead wrasse (Thalassoma bifasciatum). Ethology 85: 199-211

Forrester, G. E. (1990). Factors influencing the juvenile demography of a coral reef fish. Ecology 71: 1666-1681

Fricke, H.W. (1970). Ökologische und verhaltensbiologische Beobachtungen an den Röhrenaalen Gorgasia sillneri und Taenioconger hassi. Z. Tierpsychol. 27: 1076-1099

Fricke, H. W. (1980). Mating systems, maternal and biparental care in triggerfish (Balistidae). Z. Tierpsychol. 53: 105-122

Gladfelter, W. B., Ogden, J. C., Gladfelter, E. H. (1980). Similarity and diversity among coral reef fish communities: a comparison between tropical western Atlantic (Virgin Islands) and tropical central Pacific (Marshall Islands) patch reefs. Ecology 61: 1156- 1168

Hamner, W. M., Carleton, J. H. (1979). Copepod swarms: attributes and role in coral reef ecosystems. Limnol. Oceanogr. 24: 1-14

Hamner, W. M., Schneider, D. (1986). Regularly spaced rows of medusae in the Bering Sea: role of Langmuir circulation. Limnol. Oceanogr. 31.171-177

Hamner, W. M., Jones, M. S., Carleton, J. H., Hauri, I. R., Williams, D. McB. (1988). Zooplankton, planktivorous fish, and water currents on a windward reef face: Great Barrier Reef, Australia Bull. mar. Sci. 42: 459-479

Hartney, B. K. (1989). The foraging ecology of two sympatric gobiid fishes: importance of behavior in prey type selection. Environ. Biol. Fish. 26: 105-118

Hobson, E. S., Chess, J. R. (1978). Trophic relationships among fishes and plankton in the lagoon at Enewetak Atoll, Marshall Islands. Fish. Bull. U.S. 76: 133-153

Hobson, E. S., Chess, J R. (1988). Trophic relations of the blue rockfish, Sebastes mystinus, in a coastal upwelling system off northern California. Fish. Bull. U.S. 86: $715-743$

Hourigan, T. F. (1989). Environmental determinants of butterflyfish social systems. Environ. Biol. Fish. 25: 61-78

Jones, G. P. (1986). Food availability affects growth in a coral reef fish. Oecologia 70: 136-139

Kimoto, K., Nakashima, J. (1988). Direct observations of copepod swarm in a small inlet of Kyushu, Japan. Bull. Seikai Reg. Fish. Res. Lab. 66: 41-58

Kingsford, M. J., MacDiarmid, A. B. (1988). Interrelations between planktivorous reef fish and zooplankton in temperate waters. Mar. Ecol. Prog. Ser. 48: 103-117

Kingsford, M. J., Wolanski, E., Choat, J. H. (1991). Influence of tidally induced fronts and Langmuir circulations on distribution and movements of presettlement fishes around a coral reef. Mar. Biol. 109: 167-180

Matsumiya, Y., Murakami, T., Suzuki, T (1980). Some ecological observations on gobies, Sagamia geneionema and Rhinogobius pflaumi in Shijiki Bay. Bull. Seikai Reg. Fish. Res. Lab. 54: 321-331 (in Japanese)

Matsumiya, Y., Takahashi, K. (1983). Feeding habit of grunt, Parapristipoma trilineatum in Shijiki Bay, Hirado Island. Bull. Seikai Reg. Fish. Res. Lab. 59; 23-32 (in Japanese)

Motoda, S. (1959). Devices of simple plankton apparatus. Mem. Fac. Fish. Hokkaido Univ. 7: 73-94

Noda, M., Gushima, K., Kakuda, S. (1990). Growth-related changes in feeding patterns of the pomacentrid fish Abudefduf vaigiensis at Kuchmoerabu Island. Jap. J. Ecol. 40: 7-17 (in Japanese)

Ohtsuka, S., Fukuura, Y., Go, A. (1987). Description of a new species of Tortanus (Copepoda: Calanoida) from Kuchinoerabu Island, Kyushu, with notes on its possible 
feeding mechanism and in-situ feeding habits. Bull. Plankton Soc. Japan 34:53-63

Popper, D., Fishelson, L. (1973). Ecology and behavior of Anthias squamipinnis (Peters, 1855) (Anthiidae, Teleostei) in the coral habitat of Eilat (Red Sea). J. Exp. Zool. 184: 409-423

Ralston, S. (1981). Aspects of the reproductive biology and feeding ecology of Chaetodon miliaris, a Hawaiian endemic butterflyfish. Environ. Biol. Fish. 6: 167-176

Reese, E. S. (1978). The study of space-related behavior in aquatic animals: special problems and selected examples. In: Reese, E. S., Lighter, F. J. (ed.) Contrasts in behavior. Wiley, New York, p. 347-374

Schultz, E. T., Warner, R. R. (1991). Phenotypic plasticity in life-history traits of female Thalassoma bifasciatum (Pisces: Labridae): 2. Correlation of fecundity and growth rate in comparative studies. Environ. Biol. Fish. 30: $333-344$

Sekiguchi, H. (1978). Acartia clausi (Copepoda: Calanoida) in the guts of planktivorous sandeels. Bull. Jap. Soc. scient. Fish. 44:695

Stevenson, R. A. Jr (1972). Regulation of feeding behavior of the bicolor damselfish (Eupomacentrus partitus Poey) by environmental factors. In: Winn, H. E., Olla, B. L. (eds.) Behavior of marine animals. 2: Vertebrates. Plenum, New York, p. 278-302

Tanaka, M., Ueda, H., Azeta, M. (1987a). Near-bottom copepod aggregations around the nursery ground of the juve-

This article was submitted to the editor nile red sea bream in Shijiki Bay. Nippon Suisan Gakk. 53 : $1537-1544$

Tanaka, M., Ueda, H., Azeta, M., Sudo, H. (1987b). Significance of near-bottom copepod aggregations as food resources for the juvenile red sea bream in Shijiki Bay. Nippon Suisan Gakk. 53: 1545-1552

Thresher, R. E. (1983). Habitat effects on reproductive success in the coral reef fish, Acanthochromis polyacanthus (Pomacentridae). Ecology 64: 1184-1199

Tribble, G. W., Nishikawa, H. (1982). An analysis of the diets of four spatially overlapping damselfishes of the genus Chromis. Japan. J. Ichthyol. 29: 267-271

Ueda, H., Kuwahara, A., Tanaka, M., Azeta, M. (1983). Underwater observations on copepod swarms in temperate and subtropical waters. Mar. Ecol. Prog. Ser. 11. $165-171$

Williams, D. McB., Hatcher, A. I. (1983). Structure of fish communities on outer slopes of inshore, mid-shelf and outer shelf reefs of the Great Barrier Reef. Mar. Ecol. Prog. Ser. 10: $239-250$

Williams, D. McB., Dixon, P., English, S. (1988). Cross-shelf distribution of copepods and fish larvae across the central Great Barrier Reef. Mar. Biol. 99: 577-589

Wolanski, E., Hamner, W. M. (1988). Topographically controlled fronts in the ocean and their biological influence. Science 241: 177-181

Yamaji, I. (1984). Illustrations of the marine plankton of Japan. Hoikusha, Osaka (in Japanese)

Manuscript first received: October 2, 1991

Revised version accepted: September 14, 1992 